\title{
TELAAH KITAB FATH AL-MUN'IM SYARAH SAHIH MUSLIM KARYA MUSA SYAHIN LASYIN (Analisis Metode Kitab Syarah Hadis)
}

\author{
Umi Aflaha ${ }^{1}$, M. Amirur Rahman ${ }^{2}$ \\ ${ }^{12}$ Institut Ilmu Al Qur'an An Nur Yogyakarta \\ Email: umiaflaha1983@gmail.com
}

\begin{abstract}
During the tabi'in period, the development of hadith syarah began to find a systematic scientific format, where the methods and approaches of hadith syarah contained in several mu'tabarah books as a model in understanding the hadith of the Prophet Muhammad began to be revealed. one of them is the book Sahih Muslim. Because of the importance of this book, many scholars have advised it. Among them are Musa Syahin Lasyin with his book Fath al-Mun'im Syarh Sahih Muslim. This paper will reveal the systematics of writing and the method of syarah used in the book.
\end{abstract}

Keywords: syarah, hadis, method, muqarin

\begin{abstract}
Abstrak: Pada masa tabi'in, perkembangan syarah hadis mulai menemukan format menjadi keilmuan yang sistematis, di mana mulai diungkap metode dan pedekatan syarah hadis yang terdapat dalam beberapa kitab-kitab mu'tabarah sebagai sebuah percontohan dalam memahami hadis Nabi Saw. salah satunya adalah kitab Sbabih Muslim. Karena pentingnya kitab ini, maka banyak ulama yang mensyarahinya. Di antaranya Musa Syabin Lasyin dengan kitabnya Fath alMun'im Syarb Sabih Muslim. Tulisan ini akan mengungkap sistematika penulisan dan metode syarah yang digunakan dalam kitab tersebut.
\end{abstract}

Kata Kunci: syarah, hadis, metode, muqarin

\section{A. Pendahuluan}

Kitab Sahih Muslim merupakan salah satu dari dua kitab hadis Sahih Bukhari dan Sabih Muslim yang paling otentik. Penyusun kitab ini bernama Muslim ibn al-Hajjaj atau lebih populer dengan nama Imam Muslim. Imam Muslim dikenal sebagai ulama yang sangat teliti dalam mempelajari hadis. Ia juga sangat teliti mempelajari para pembawa berita hadis (perawi).

Para ulama hadis yang berupaya meneliti kitab ini menemukan bahwa hadishadis yang ditulis oleh Imam Muslim di dalam kitab Sabibnya, diriwayatkan oleh orangorang adil, kuat hafalannya (dabith) dan dapat dipertanggungjawabkan keabsahannya. Kriteria ini pada umumnya digunakan para ulama hadis sebagai syarat diterimanya suatu hadis. 
Sabih Muslim merupakan kitab hadis yang paling banyak digunakan sebagai rujukan untuk mendapatkan hadis-hadis shahih dari Rasulullah Saw. Dalam kitabnya ini, Imam Muslim menyimpan sekitar enam ribu lima ratus hadis ${ }^{1}$ dengan sedikit pengulangan pada hadis-hadisnya. Semua hadis-hadis itu beliau susun menjadi lima puluh empat kitab, dimulai dari kitab Al Iman sampai kitab ke lima puluh empat yaitu kitab tafsir. Sabih Muslim ini merupakan kitab yang cukup menjadi perhatian banyak ulama untuk memberikan penjelasan atasnya. Hal ini tidaklah mengherankan karena kitab Sabih Muslim disepakati oleh mayoritas ulama merupakan kitab hadis paling shahih setelah kitab Sabih Bukhari.

Di antara kitab syarah Sabih Muslim yang dibuat oleh ulama abad keenam seperti Al-Mu'lim bi Fawaid al-Muslim, karya Imam al-Maziriy (w. 536 H), Ikmal alMu'lim, karya Abu al-Fadl 'Iyad ibn Musa al-Yahsabi (w. 544). Ada juga dari ulama abad ketujuh seperti al-Mufhim lima Asykala min Talkhis Kitab Muslim, karya Abu al'Abbas al-Qurtubi (w. 656 H). Karya ulama abad kedelapan seperti kitab Mukbtasar Sabih Muslim bi Syarh al-Nawawi karya Syeikh Syamsuddin Muhammad Ibn Yusuf alQunawi al-Hanafi (w. 788 H). Karya ulama abad kesembilan seperti Ikmal Ikmal alMu'allim, karya Abu 'Abdillah Muhammad ibn Khalifah al-Wasytani (w. 828), Mukammil Ikmal Ikmal, karya Abu 'Abdillah Muhammad ibn Muhammad ibn Yusuf alTanusi (w. 895). Karya ulama abad kesepuluh seperti kitab al-Dibaj 'ala Sabib Muslim ibn Hajjaj karya al-hafiz Jalaluddin ibn 'Abdirrahman ibn Abi Bakr al-Suyuti (w. 911 H). Di antara kitab syarah yang masyhur juga adalah Al-Minhaj Syarb Sabih Muslim ibn Hajjaj karya Imam al-Nawawi (w. $676 \mathrm{H}$ ) atau yang lebih dikenal dengan nama Syarb alNawawi Muslim. Maka, dalam tulisan ini penulis akan membahas tentang karya ulama abad kontemporer, yaitu kitab Fath al-Mun'im Syarb Sabib Muslim karya Musa Syahin Lasyin (w. 2009 M). ${ }^{2}$

Kajian metode syarah hadis, baik secara teoritis dan praktis telah dilakukan oleh banyak pengkaji hadis, yaitu: Pertama, Saifuddin dengan judul FIQH ALHADITS: Perspektif Historis dan Metodologis. Artikel ini membahas bahwa metodologi

\footnotetext{
${ }^{1}$ Merujuk pada penomeran hadis di dalam Syarah Muslim karya Musa Syahin Lasyin, Fath alMun'im S yarh Shahih Muslim. (Kairo: Dar al-Syuruq, 2002). Juz 10, hlm. 648.

${ }^{2}$ Farham Walidin, "Metode Syarah Syekh Syafiurrahman al-Mubarakfurry dalam Minnah alMun'im Syarh Shahih diakses dari https://uinsgdbandung.academia.edu/Departments/Tafsir_Hadis/Documents
} 
fiqh al-hadis atau syarah hadis mengalami perkembangan secara bertahap dari tarajim alhadis, kemudian menjadi syarh (penjelasan) dan lebih belakangan lagi mengambil bentuk ta'qib (komentar) dan ta'liq (anotasi). ${ }^{3}$ Kedua, Moh. Muhtador dengan judul Sejarah Perkembangan Metode dan Pendekatan Syarah Hadis. Dalam artikelnya Muhtador menyimpulkan bahwa syarah hadis menjadi disiplin ilmu dan terpisah dari hadis pada masa tabi'in dengan menggunakan berbagai metode dan pendekatan. ${ }^{4}$ Ketiga, Sandi Santosa dengan judul Melacak Jejak Pensyarahan Kitab Hadis yang menemukan bahwa kondisi social politik dan keagamaan telah mempengaruhi perkembangan syarah kitab hadis sehingga mengikuti alur kecenderungan madzhab yang ada. ${ }^{5}$ Keempat, A. Hasan Asy'ari Ulama’i dengan judul Sejarah dan Tipologi Syarah Hadis. Dalam artikel ini dikemukakan tentang sejarah awal syarah hadis dan beberapa macam cara ulama mensyarah suatu hadis. ${ }^{6}$

Beberapa penelitian di atas menunjukkan belum adanya pembahasan terhadap metode kitab syarah hadis, khususnya kitab Fath al-Mun'im Syarh Sabih Muslim karya Musa Syahin Lasyin. Oleh karena itu, tulisan ini akan membahas penelitian lanjutan agar metode syarah kitab Fath al-Mun'im Syarh Sabih Muslim dapat dipahami secara seksama dan mendalam. Selain itu, persoalan akademik lain yang akan dipaparkan di dalam tulisan ini adalah menelisik lebih dalam tentang kecenderungan madzhab pensyarah dalam kitabnya yang digunakan untuk memahami hadis Nabi Saw.

\section{B. Hasil dan Pembahasan}

\section{Pensyarahan Hadis dan Metode Syarah Hadis}

Periode pensyarahan hadis dimulai sejak tahun $656 \mathrm{H} / 1258 \mathrm{M}$, di mana kekhalifahan Abbasiyah di Baghdad ditaklukkan oleh tentara Tartar. Pada era inilah penulisan kitab syarah hadis begitu banyak dilakukan. Hal ini sangatlah wajar, karena para ulama saat itu sudah tidak lagi disibukkan oleh aktifitas

\footnotetext{
${ }^{3}$ Saifuddin, "FIQH AL-HADITS: Perspektif Historis dan Metodologis, Ilmu Ushuluddin, Vol. 11, No. 2, Juli 2012.

${ }^{4}$ Moh. Muhtador, "Sejarah Perkembangan Metode dan Pendekatan Syarah Hadis", Riwayah: Jurnal Studi Hadis, Vol. 2, No. 2, 2016.

${ }^{5}$ Sandi Santosa, "Melacak Jejak Pensyarahan Kitab Hadis”, Diroyah: Jurnal Studi Ilmu Hadis, Vol. 1, No. 1, 2016.

${ }^{6}$ A. Hasan Asy'ari Ulama'I, “Sejarah dan Tipologi Syarah Hadis”, Teologia, Vol. 19, No. 2, Juli 2008.
} 
sistematisasi kitab kumpulan hadis, penelitian dan penambahan-penambahan hadis dalam suatu kitab, akan tetapi mereka berupaya menjelaskan makna-makna hadis Nabi saw. yang telah dihimpun dalam kitab-kitab hadis agar dapat dipahami dan diamalkan oleh umat Islam.

Di antara kitab-kitab syarah hadis pada masa itu adalah: Kasf al-Ghitha' fi Syarh Mukhtashar al Muwaththa' karya Abu Muhammad bin Abil Qasim alFarhuni al-Ya'muri al-Tunisi (w. 763 H), Fath al-Bari bi Syarb Shabih al-Bukbari karya Ibn Hajar al-Asqalani (w. 852 H), Irsyad al-Sari ila Syarb al-Shabih al-Bukhari karya Syihabuddin Ahmad ibn Muhammad al-Khathib al-Qasthalani (w. $925 \mathrm{H}$ ), Aun al-Ma'bud Syarb Sunan Abi Daud karya Muhammad ibn Asyraf al-Abady dan masih banyak lagi yang lainnya.

Adapun metode syarah yang digunakan oleh kitab-kitab tersebut beragam. Menurut M. Alfatih Suryadilaga ada beberapa metode ulama dalam mensyarah hadis, yaitu: ${ }^{8}$

a. Ijmali; menjelaskan hadis sesuai dengan urutan dalam kitab kumpulan hadis secara ringkas dengan bahasa yang mudah dipahami. Penjelasannya sangat global, karena hanya menyebutkan makna harfiahnya, cukup singkat dan tanpa menyinggung hal-hal selain arti yang dikehendaki.

b. Tablili; menguraikan, menganalisis, dan menjelaskan makna-makna yang terkandung dalam hadis Nabi Saw. dengan memaparkan aspek-aspek yang terkait keahlian dan kecenderungan pensyarah. Penjelasannya menyangkut berbagai aspek seperti penjelasan kosa kata, susunan kalimat dalam segi bahasa, asbabul wurud (jika ditemukan), kaitannya dengan hadis-hadis lain, pendapat-pendapat ulama yang beredar di sekitar pemahaman hadis tersebut, baik yang berupa dari sahabat, tabi'in maupun dari para ulama hadis.

c. Muqarin; menjelaskan hadis dengan cara: (1) membandingkan hadis yang memiliki redaksi yang sama atau mirip dalam kasus yang sama atau memiliki

${ }^{7}$ A. Hasan Asy'ari Ulama'I, "Sejarah dan Tipologi Syarah...., hlm. 348.

${ }^{8}$ M. Alfatih Suryadilaga, Metodologi Syarah Hadis, (Yogyakarta: Kalimedia, 2017), hlm. 1645. 
redaksi yang berbeda dalam kasus yang sama, dan (2) membandingkan berbagai pendapat ulama hadis dalam menjelaskan suatu hadis.

\section{Biografi Musa Syahin Lasyin}

Musa Syahin lahir dan besar di desa Asnet yang terletak di kabupaten Benha provinsi Qalyubiyyah, pada tanggal 6 April 1920 M. Musa Syahin tumbuh besar dalam keluarga yang berkecukupan. Seperti anak-anak kecil pada umumnya di perkampungan Mesir, ia mengkhatamkan al-Qur'an di Kuttab, sejenis TPQ di desanya dan kebetulan yang mengajar di sana adalah kakaknya yang bernama Gouda. Musa Syahin menempuh jenjang pendidikan formalnya di sekolah dasar dan menengah pada lembaga pendidikan di al-Azhar (ma'had al-Az̧har). Ia termasuk orang pertama dari desanya yang mengenyam pendidikan ma'had al-Ažhar di Tanta sampai ia tamat dari Madrasah Aliyah. Kemudian ia melanjutkan kuliahnya di Fakultas Ushuludin. Pada tahun 1946, ia menyelesaikan program S1 nya dan meraih gelar Lc. Setelah itu ia melanjutkan pasca sarjananya di Fakultas Bahasa Arab dan meraih gelar magister tahun 1948, lalu ia melanjutkan S3 nya di Fakultas Ushuluddin jurusan Tafsir Hadis dan meraih doktoral tahun 1965. Sebagai pengamalan ilmunya ia mengabdi sebagai pengajar tafsir hadis di ma'bad Al-Azhar selama puluhan tahun mulai 1948 sampai tahun 1965. Kemudian ia dipilih oleh Universiatas al-Azhar sebagai pengajar mata kuliah hadis pada tahun 1965 dan menjadi dosen tetap tahun 1971. Berkat kesungguhannya dalam mengajarkan ilmunya, ia dikukuhkan sebagai guru besar, kemudian menjabat kepala jurusan hadis Fakultas Ushuluddin pada tahun 1976, lalu diangkat menjadi dekan pada tahun 1979 sampai 1982. Karir terakhirnya di al-Azhar adalah sebagai wakil rektor bidang pasca sarjana dan riset. Di samping itu, di luar alAzhar ia menjabat ketua Pusat Studi Sirah dan Sunnah di bawah naungan kementerian wakaf dari tahun 1994 sampai wafatnya. Ia juga pernah ditugaskan ke luar negeri selama mengabdi di al-Azhar, di antaranya ia pernah ditugaskan ke Saudi Arabia, Kuwait, Libya, Somalia dan Qatar. ${ }^{9}$

Beberapa sumbangsih Musa Syahin adalah proyeknya membuat ensiklopedi sunnah (takhri hadis, menghukumi hadis dengan metode ilmiah). Ia adalah penemu

\footnotetext{
${ }^{9}$ Muhammad Aniq Imam, “Problematika Sunnah Tasyri'iyyah dan Ghairu Tasyri'iyyah, jurnal ADDIN, Vol. 7, no. 2, Agustus 2013, hlm. 383-384.
} 
metode dalam proyeknya yang kemudian diterapkan dan disempurnakan oleh para muridnya, para mahasiswa pascasarjana al-Azhar sampai sekarang dalam menulis thesis dan disertasi. Selama hidupnya ia masih tetap menyempatkan diri sebagai pembimbing bagi murid-muridnya dalam menulis thesis atau disertasi sejak tahun 1976 sampai wafatnya. Ia juga menjadi pembimbing dan penguji lebih dari 200 thesis atau disertasi di Universits al-Azhar, Universitas Alexandria di Mesir, Universitas Ummul Qura dan Imam bin Saud di Saudi Arabia dan Universitas Um Durman di Sudan. Selain itu, ia mengajar mahasiswa pascasarjana di Mesir, Saudi Arabia, Libya dan Qatar selama 30 tahun. Ia juga ikut berpartisipasi dalam meluruskan pemahaman yang salah tentang Islam, ia berdakwah melalui media televisi dan radio yang rekamannya mencapai 1000 episode di Mesir, 500 episode di Qatar, 50 episode di Saudi dan 20 episode di radio BBC London seksi bahasa Arab. Ia juga menyumbangkan pemikirannya untuk media massa Arab dan Islam berupa 1000 fatwa, 50 artikel di koran Mesir, 10 artikel di koran Qatar dan 5 artikel di koran Saudi Arabia. ${ }^{10}$

Di antara karyanya adalah Taysir Tafsir an-Nasafi (15 juz) yang dimasukkan dalam kurikulum mata pelajaran tafsir di tingkat Madrasah Aliyah (ma'bad Al-Az̧har), al-Lali al-Hisan fi 'Ulum al-Qur'an, al-Manhal al-Hadis | fi Syarh Hadis al-Bukhari (4 juz), Fath al-Mun'im Syarh Sabih Muslim (10 jilid) yang patut mendapat prestise magnum opus, merupakan syarah Sabih Muslim paling kontemporer dan terlengkap, yang memakan waktu 25 tahun dalam penulisannya, Qasas min Hadis Nabawi (2 jilid), Sabih Bukhari fi Nizam Jadid (4 jilid), al-Sunnah wa al-Tasyri', al-Sunnab Kulluba Tasyri', al-Husun al-Mani'ah li ad-Difa' 'an al-Sunnah, Tajdid al-Din. Karyanya yang belum dicetak di antaranya AlSalsabil al-Jari Syarb Sabih al-Bukhari, Taysiru Ma'ani al-Qur'an, Al-Mubassat fi Mustalah alHadis.

Akhir hayatnya ditutup dengan kisah yang indah. Ia meninggalkan dunia fana ketika masih dalam tahap menyempurnakan karnya, yaitu kitab al-Salsabil al-Jari Syarh Sabih al-Bukhari, jilid keenam. Ketika ia ingin beristirahat dari menulis, ia bewudhu untuk shalat dua rakaat lalu tidur berbaring ke sebelah kanan menghadap kiblat. Saat dalam kondisi tidur itulah Allah menahan ruhnya dan tidak mengembalikannya lagi. Ia

${ }^{10}$ Muhammad Aniq Imam, "Problematika Sunnah Tasyri'iyyah ...., hlm. 384 
meninggalkan dunia dalam kondisi tersebut di rumahnya di Naser City, Cairo pada 6 Januari 2009 saat umur 89 tahun. ${ }^{11}$

\section{Mengenal Kitab Fath al-Mun'im Syarh Sahih Muslim}

\section{a. Latar Belakang Penulisan}

Melihat latar belakang Musa Syahin sebagai ahli tafsir hadis di Universitas al-Azhar, kitab Fath al-Mun'im ini adalah karangan beliau yang didedikasikan sebagai bahan ajar di madrasah al-Azhar setelah melihat bahwa kurikulum yang digunakan saat itu adalah hadis Sabih Muslim. Sementara itu kitab hadis Sabih Muslim belum ada syarahnya (penjelasannya) seperti kitab hadis Sabih Bukhari. Oleh karena itu, beliau berusaha untuk menulis syarah dari kitab Sabih Muslim yang dimaksudkan untuk mempermudah dalam memahami kitab Sabih Muslim itu sendiri. Pada proses penulisannya, beliau didukung oleh banyak pihak, dan beliau berharap agar kitab ini bisa memberi pemahaman tentang hadis Nabi saw. kepada semuanya, terutama kepada civitas akademika Universitas al-Azhar sendiri. Kitab ini beliau susun dengan bahasa yang sistematis sesuai dengan kurikulum Universitas al-Azhar fakultas Ushuluddin jurusan Tafsir dan Hadis. ${ }^{12}$

\section{b. Sistematika Penulisan Kitab}

Kitab ini disusun dengan mengikuti sistematika kitab Sabih Muslim yakni dengan menempatkan hadis-hadis dalam sebuah kitab yang kemudian dibagi menjadi beberapa bab. Berikut tabel sistematika ${ }^{13}$ dari penulisan kitab Sabih Muslim.

\footnotetext{
${ }^{11}$ Majalah al-Wa'y al Islamiy, Kuwait: edisi 523 Rabi' al Awwal 1430 H./ ADDIN, Vol. 7, No. 2,2013

${ }^{12}$ Musa Syahin Lasyin, Mukaddimah kitab Fath al-Mun'im Syarh Sahih Muslim (Kairo: Dar al-Syuruq, 2002).

${ }^{13}$ Dosen TH Fakultas Ushuluddin UIN Sunan Kalijaga. Studi Kitab Hadis (Yogyakarta: Teras, 2009), hlm 68-69.
} 
An-Nur: Jurnal Studi Islam Volume 11 Nomor 2 Tahun 2019

P-ISSN 1829-8753, E-ISSN 2502-0587

\begin{tabular}{|c|c|c|c|}
\hline \multirow[t]{2}{*}{ No } & \multirow[t]{2}{*}{ Nama Kitab } & \multicolumn{2}{|c|}{ Jumlah } \\
\hline & & Bab & Hadis \\
\hline- & Muqaddimah & 74 & - \\
\hline 1 & Al-Iman & 96 & 280 \\
\hline 2 & Al-Taharah & 34 & 111 \\
\hline 3 & Al-Haid & 33 & 126 \\
\hline 4 & Al-Salah & 52 & 285 \\
\hline 5 & Masajid wa Mawadi' al-Salah & 56 & 316 \\
\hline 6 & Salah al-Musafirin wa Qasriha & 56 & 312 \\
\hline 7 & Al-Jum'ah & 19 & 73 \\
\hline 8 & Al-'Aidain & 5 & 22 \\
\hline 9 & Al-Istisqa’ & 5 & 17 \\
\hline 10 & Al-Kusuf & 5 & 29 \\
\hline 11 & Al-Janaiz & 37 & 108 \\
\hline 12 & Al-Zakah & 56 & 177 \\
\hline 13 & Al-Siyam & 40 & 222 \\
\hline 14 & Al-I'tikaf & 4 & 10 \\
\hline 15 & Al-Hajj & 97 & 522 \\
\hline 16 & Al-Nikah & 24 & 110 \\
\hline 17 & Al-Rada' & 19 & 32 \\
\hline 18 & Al-Talaq & 9 & 134 \\
\hline 19 & Al-Li'an & 1 & 20 \\
\hline 20 & Al-'Atg & 7 & 26 \\
\hline 21 & Al-Buyu’ & 21 & 123 \\
\hline 22 & Al-Masaqah & 31 & 143 \\
\hline 23 & Al-Faraid & 5 & 21 \\
\hline 24 & Al-Hibah & 4 & 32 \\
\hline 25 & Al-Wasiyyah & 6 & 22 \\
\hline 26 & Al-Naz|ar & 5 & 13 \\
\hline 27 & Al-Aiman & 13 & 59 \\
\hline
\end{tabular}


An-Nur: Jurnal Studi Islam Volume 11 Nomor 2 Tahun 2019

P-ISSN 1829-8753, E-ISSN 2502-0587

\begin{tabular}{|l|l|l|l|}
\hline 28 & $\begin{array}{l}\text { Al-Qasamah wa al-Maharibin } \\
\text { wa al-Qisas wa al-Diyat }\end{array}$ & 11 & 29 \\
\hline 29 & Al-Hudud & 11 & 46 \\
\hline 30 & Al-Aqdiyah & 11 & 21 \\
\hline 31 & Al-Luqatah & 6 & 19 \\
\hline 32 & Al-Jihad & 51 & 150 \\
\hline 33 & Al-Imarah & 56 & 185 \\
\hline 34 & $\begin{array}{l}\text { Al-Said wa al-Z|abaih wa ma } \\
\text { yu'kilu min al-hayawan }\end{array}$ & 12 & 60 \\
\hline 35 & Al-Adaha & 8 & \\
\hline 36 & Al-Asyribah & 35 & 45 \\
\hline 37 & Al-Libas & 35 & 188 \\
\hline 38 & Al-Adab & 10 & 127 \\
\hline 39 & As-Salam & 41 & 45 \\
\hline 40 & Al-Fadail & 5 & 155 \\
\hline 41 & Al-Syi'ir & 2 & 21 \\
\hline 42 & Al-Ru'ya & 5 & 10 \\
\hline 43 & Al-Fadail & 36 & 23 \\
\hline 44 & Fadail al-Sahabah & 60 & 174 \\
\hline 45 & Al-Birr wa al-silah wa al-adab & 51 & 232 \\
\hline 46 & Al-Qadar & 8 & 166 \\
\hline 47 & Al-“'Ilmu & 6 & 34 \\
\hline 48 & $\begin{array}{l}\text { Al-Z|ikr wa al-du'a' wa al- } \\
\text { taubah wa al-istighfar }\end{array}$ & 27 & 16 \\
\hline 49 & At-Taubah & 11 & 34 \\
\hline 50 & Sifat al-munafiqin & 1 & 83 \\
\hline 51 & $\begin{array}{l}\text { Al-Jannah wa sifat nafsiha wa } \\
\text { ahliha }\end{array}$ & 40 & 34 \\
\hline 52 & Al-Fitan wa syarait al-sa'ah & 28 & \\
\hline 53 & Al-Zuhd wa al-Rafaiq & 20 & 83 \\
\hline 54 & Al-Tafsir & 8 & \\
\hline
\end{tabular}


Langkah-langkah penulisan dalam kitab Fath al-Mun'im Syarb Sabih Muslim sebagai berikut:

1) Mencantumkan tema bab, kemudian penulisan matan hadis dan nomer dari setiap bab (bukan nomer hadis dari kitab Sabih Muslim), akan tetapi tidak menyebutkan sanad dengan lengkap, kecuali rawi pertama dari tingkat sahabat.

2) Tidak ada pembahasan tentang status hadis dan kualitas para rawi. Hal ini dimungkinkan karena hadis-hadis dalam kitab Sabib Muslim dinilai shahih oleh sebagian besar ulama.

3) Syarah hadis ditulis dengan pembahasan sebagai berikut: ${ }^{14}$

a) المعنى العام

Pada bagian ini Musa Syahin menjelaskan matan hadis secara umum dengan ungkapan yang sederhana dan gaya bahasa yang mudah dipahami.

b) المباحث العربية

Pada bagian ini Musa Syahin menjelaskan kata perkata atau susunansusunan kalimat dalam matan hadis dengan pendekatan bahasa, baik yang terkait dengan nahwu dan balaghah.

c) فقه الحديث

Pada bagian ini Musa Syahin menjelaskan hadis dari segi hukumhukum syar'i, menampilkan riwayat-riwayat yang berbeda-beda, menyebutkan pendapat-pendapat para ulama tentang penerimaan atau penolakan suatu hadis, menguatkan pendapatnya dengan dalil al-Qur'an dan menguraikan beberapa hikmah dan faedah yang dapat diambil dari hadis yang disyarah.

juz 1 , hlm. 8

${ }^{14}$ Musa Syahin Lasyin, Fath al-Mun'im Syarh Sahih Muslim (Kairo: Dar al-Syuruq, 2002), 


\section{Metode Syarah Hadis}

Penulis akan memberikan contoh syarah hadis dalam kitab Fath al-Mun'im agar lebih mengetahui tentang gambaran metode dalam kitab ini. ${ }^{15}$

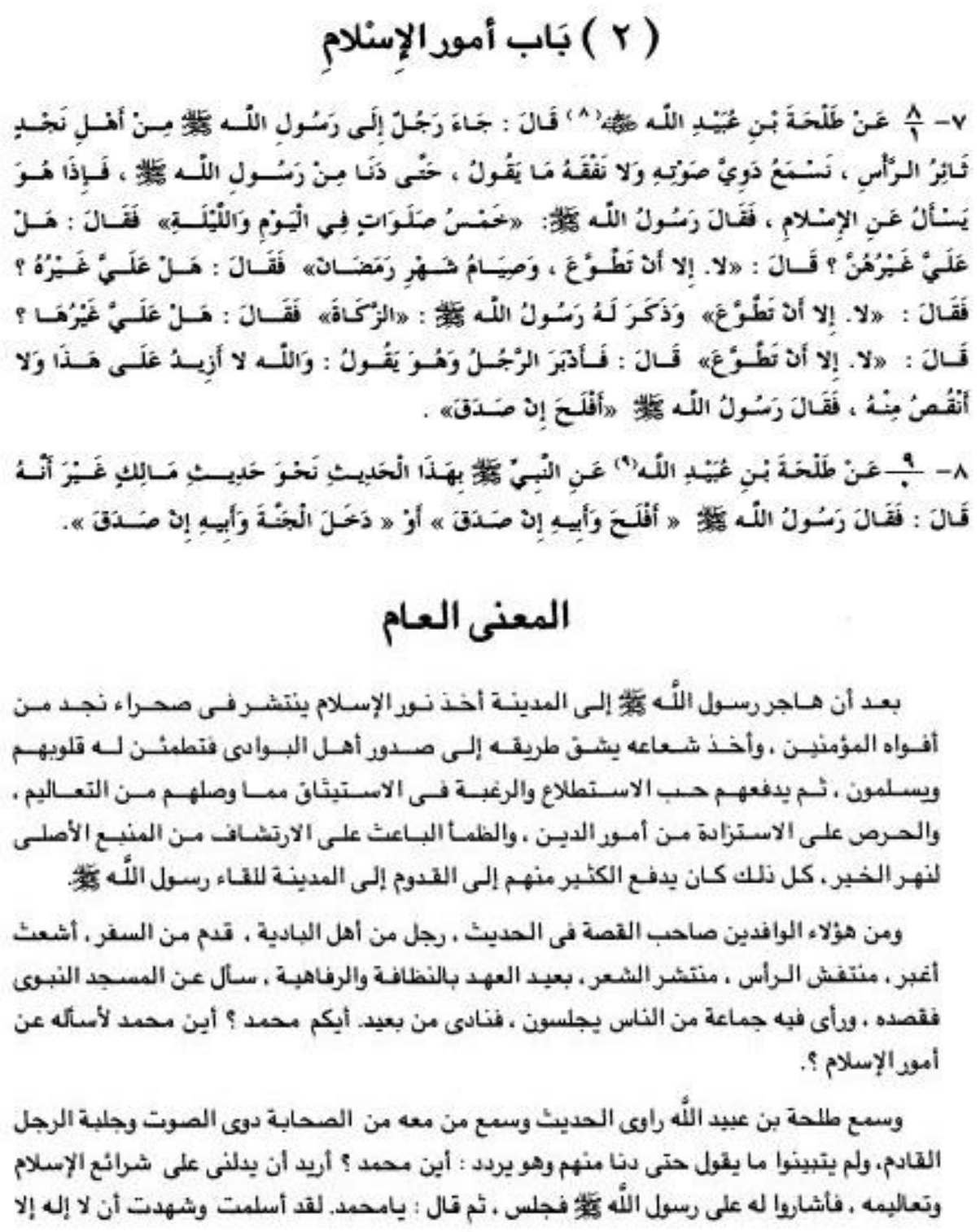

\section{المعنى العـام}

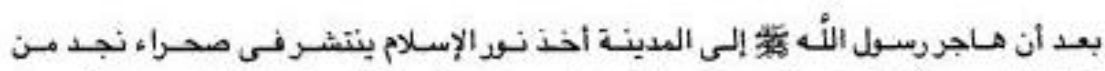

\footnotetext{
${ }^{15}$ Musa Syahin Lasyin, Fath al-Mun "im Syarh Sahih Muslim, Kairo: Dar al-Syuruq, 2002), juz 1, hlm. 34-39.
} 


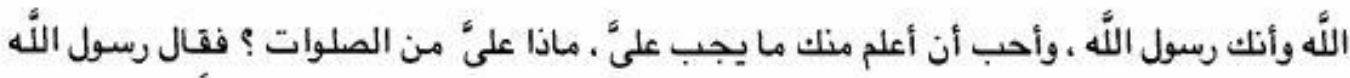

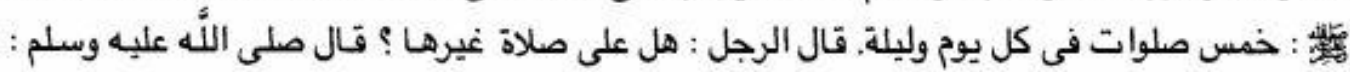

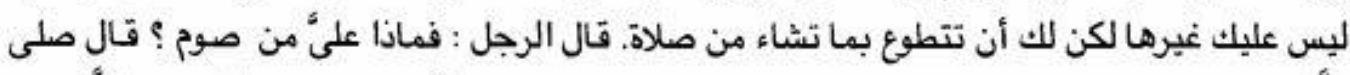

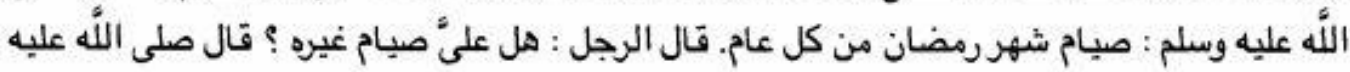

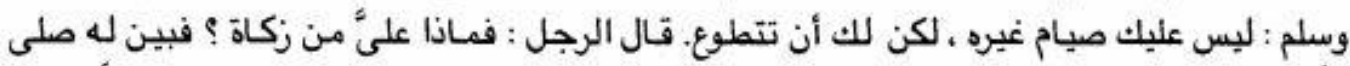

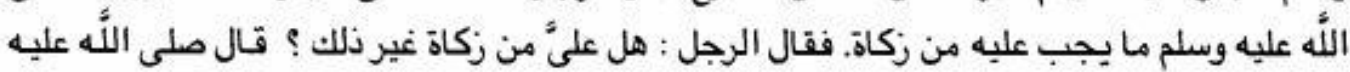

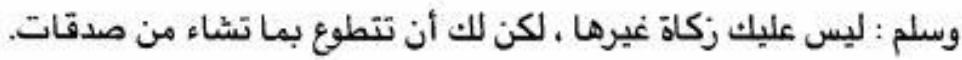

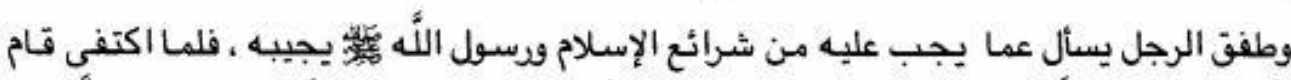

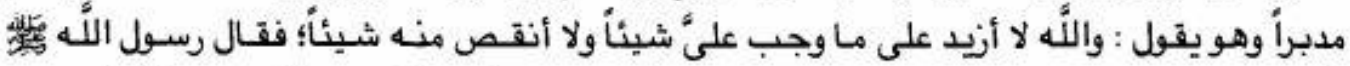
لأصحابه : إن صدق هذا الرجل فيما قال ـ ووفى بما التزم دخل الجنة وكان التحان من المفلحين الفائزين.

\section{المباحث العريية}

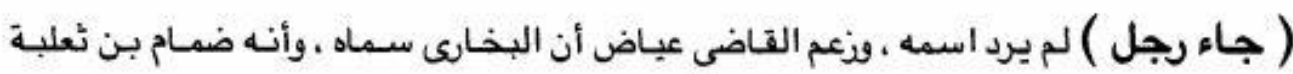

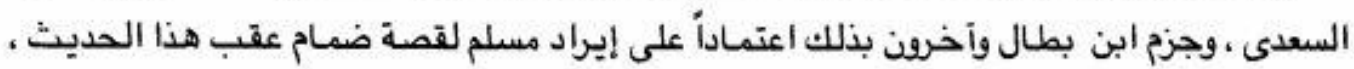

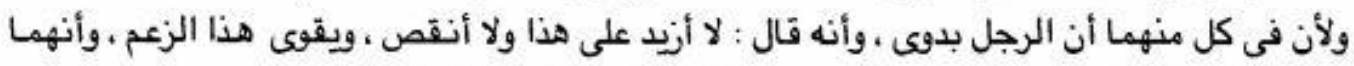

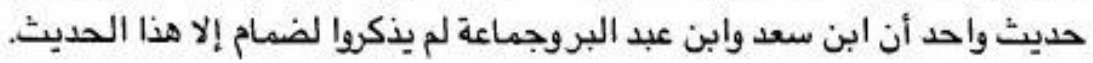

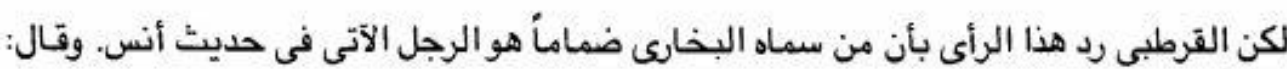

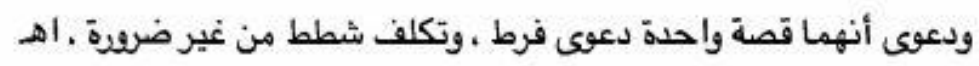

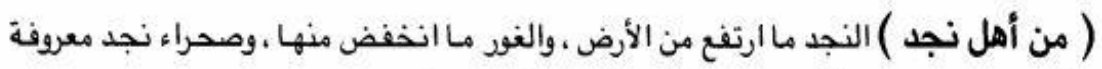
شرق الحجاز، سميت نجداً لارتفاعها. والغور المقابل لها تهامة.

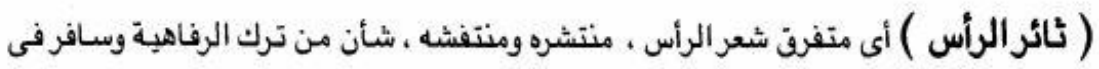

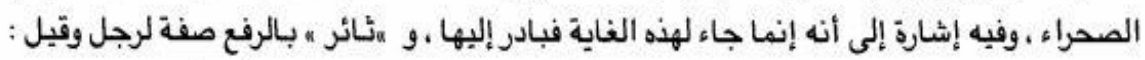

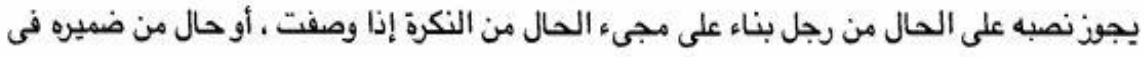

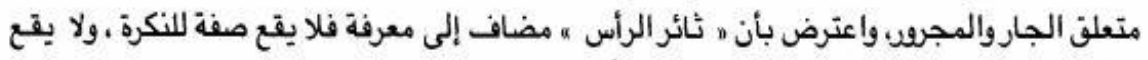
حالا ، وأجيب بأن إضافته لفظلية لا تفيد تعريفاً. وفى الكلام مضاف محذوف تقديره : ثائر شعر الرأس.

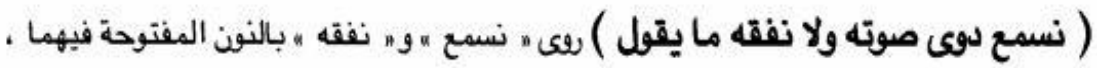

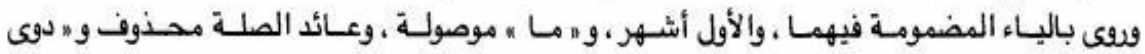

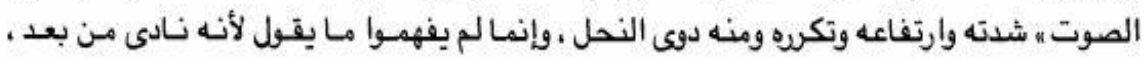
متعجلا السؤال ، فلما دنا فهم كلامه ، لهذا قال : 


\title{
فقه الحديث
}

\begin{abstract}
استدل الحنفية والمالكية بالحديث على أن الشروع بالتطوع يوجب إتمامه ، تمسكا بأن الأصل

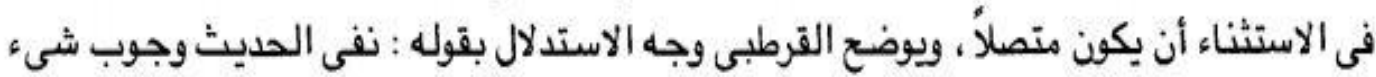

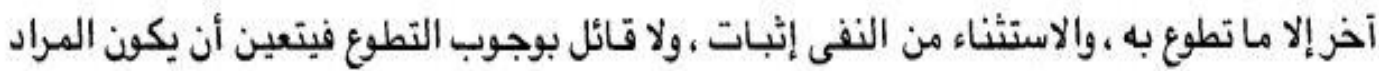

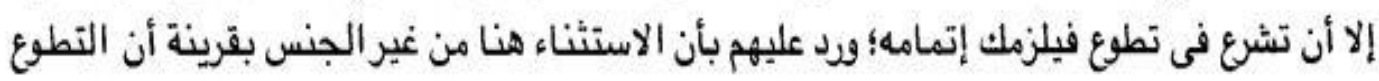

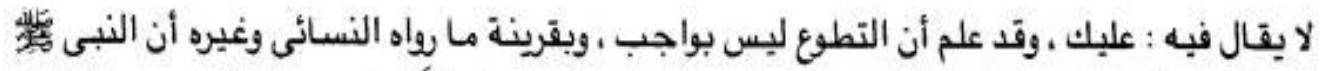

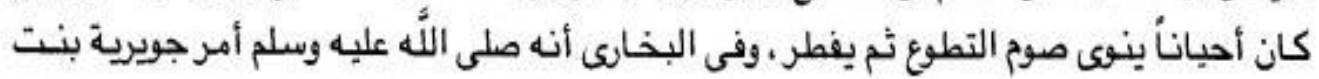

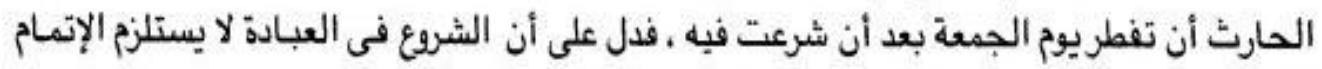
إذا كانت نافلة؛ بهذا النص فى الصوم والقياس فى الباقى فئ.

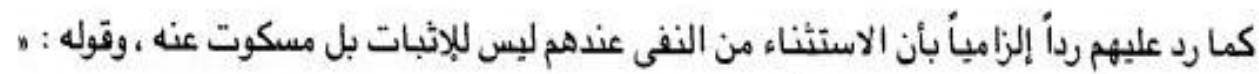

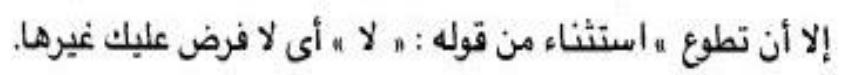

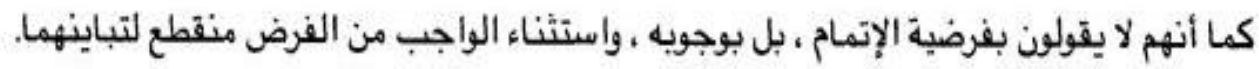
وقد أورد على الحديث إشكالات نعرضها مع الإجابة عليها.

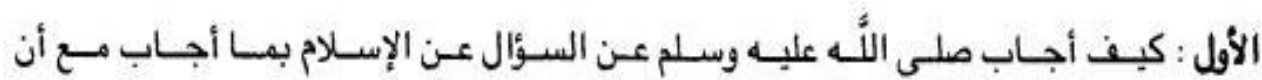

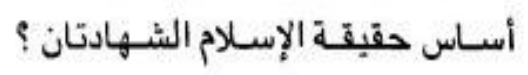

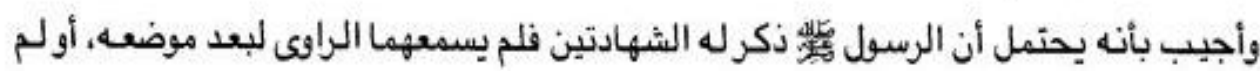
4

Musa Syahin mensyarah atau menjelaskan bahwa المعنى العام dari hadis tentang bab dalam perkara-perkara Islam (fi umur al-islam) di atas adalah bahwa setelah Nabi hijrah ke Madinah, Islam menyebar luas di kalangan penduduk padang pasir Najd sehingga sampai pula pada orang-orang badui. Mereka penasaran dan semangat untuk belajar tentang perkara-perkara agama. Begitu pula mereka sangat ingin mendapat pengetahuan langsung dari sumber aslinya. Oleh karena itu, banyak dari mereka datang ke Madinsh untuk bertemu dengan Rasul Saw. Salah satu dari mereka adalah seseorang yang disebut pada hadis tersebut di atas sebagai seorang 
badui yang datang dari perjalanan jauh dengan rambut acak-acakan, bertubuh pendek, jauh dari kesan kebersihan dan kerapian lagi bersikap kebingungan. Ia mencari masjid Nabi. Ketika ia mendapatinya, ia melihat sekumpulan orang dudukduduk, lalu ia memanggil-manggil dari jauh: "Yang mana namanya Muhammad? Mana Muhammad? Aku ingin bertanya tentang perkara-perkara Islam.” Kemudian Nabi saw. menjawab setelah sahabat Talhah ibn 'Abdullah memberitahunya tentang orang badui tersebut: "Bahwa perkara-perkara Islam itu adalah sholat 5 waktu sehari semalam beserta sholat sunnahnya, puasa Ramadhan setiap tahun beserta puasa sunnahnya, zakat yang wajib dan sedekah-sedekah yang sunnah. Mendengar jawaban Nabi, orang badui itu berkata: "Demi Allah, aku tidak akan menambah apa-apa yang telah diwajibkan dan tidak pula aku akan menguranginya sedikitpun.” Setelah itu, Nabi Saw. bersabda pada sahabat-sahabatnya: “jika perkataan dan pebuatan laki-laki ini benar, makai masuk surga dan termasuk orang-orang yang beruntung, lagi menang.

Selanjutnya Musa Syahin menjelaskan beberapa susunan kalimat pada bagian dari hadis tersebut sebagai berikut:

a. جاء رجل : dalam hadis tidak disebutkan siapa seseorang di sini. Menurut alQadi 'Iyad bahwa al-Bukhari menyebutkan namanya, yaitu Dimam ibn S | a'labah al-Sa'di. Demikian pula bahwa Ibn Sa'ad, Ibn 'Abd al-Bar dan yang lain tidak menyebut Dimam kecuali dalam hadis ini.akan tetapi al-Qurtubi menolaknya.

b. تأثر الرأس : rambutnya acak-acakan, berantakan karena perjalanan melewati padang pasir. Ini menunjukkan bahwa ia datang terburu-buru karena suatu tujuan. Lafadz ini bisa dibaca dengan i'rab rafa' sebagai sifat (na'at) dan bisa juga dibaca dengan i’rab nasab sebagai hal (menjelaskan keadaan).

c. نسمع ذوى صوته ولا نفقه ما يقول : ada yang meriwayatkan dengan nun berfathah dan ada yang meriwayatkan dengan ya' berdhammah, akan tetapi pendapat pertama yang lebih masyhur. L di sini berfungsi sebagai mausul (kata penghubung), akan tetapi isim yang terkait dengannya mahz|uf (dibuang). Karena betapa kerasnya suara orang tersebut para sahabat Nabi tidak paham apa yang ia katakan akibat ia memanggil dari kejauhan dan cepat-cepat. Tetapi ketika ia mendekat, para sahabat pun dapat memahami perkatannya. 
Kemudian pada penjelasan فقه الحديث atau syarah hadisnya Musa Syahin menyebutkan bahwa madzhab Hanafi dan Maliki menggunakan hadis ini sebagai dalil bahwa melaksanakan yang sunnah harus disempurnakan. Sudah diketahui jika hal yang sunnah tidaklah wajib. Ini berdasarkan petunjuk hadis yang diriwayatkan oleh al-Nasa’i bahwa Nabi saw. terkadang niat puasa sunnah kemudian berbuka. Begitu juga hadis yang diriwayatkan al-Bukhari bahwa Nabi saw. menyuruh Juwairiyah binti al-Haris | berbuka pada hari Jum'at. Maka ini menunjukkan bahwa disyari'atkannya ibadah tidak harus dipenuhi apabila hukumnya sunnah.

Dari uraian di atas dapat diketahui bahwa Musa Syahin dalam pensyarahannya melakukan perbandingan-perbandingan. Salah satunya dengan menyebutkan hadis lain yang terkait dengan hadis tersebut di atas. Selain itu, dapat menyebutkan asbab al-wurud, di mana pada hadis tersebut asbab al-wurudnya memang langsung termaktub di dalamnya. Ini penting untuk mengetahui makna tekstual hadis tersebut dari fakta historis dan dan fakta social yang terjadi saat itu. Kemudian menjelaskan lafadz yang sulit dipahami dan dari aspek kebahasaannya, seperti mencantumkan penjelasan tentang harf dan syakl, nahwu dan makna lughawi. Dari sini dapat dipahami bahwa pendekatan yang digunakan adalah pendekatan bahasa. Dalam hal ini pula ada perbandingan antara pendapat ulama mengenai nama seseorang yang disebut dalam hadis tersebut dan cara baca pada 2 fi'il ( نسمع dan نفقه).

Perbandingan berikutnya adalah mengemukakan pendapat para imam madzhab bahwa kelompok Hanafi dan Maliki berpendapat bahwa ibadah sunnah harus (wajib) disempurnakan pelaksanaannya. Sedangkan madzhab lain tidak wajib. Sedangkan yang dimaksud dengan kemenangan di sini adalah selamat dari api neraka sebagaimana firman Allah dalam QS. Ali Imran ayat 85:

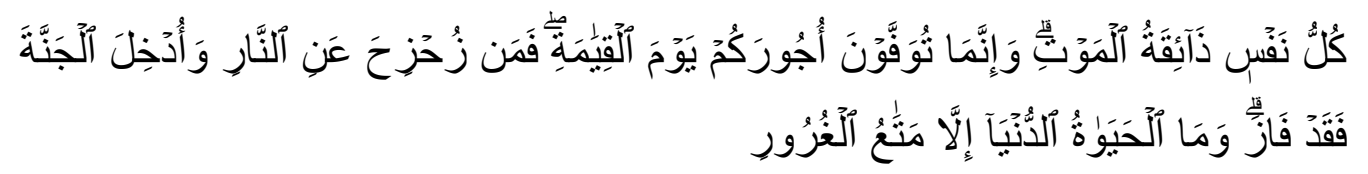


Di akhir syarahnya Musa Syahin menyebutkan beberapa ibrah yang dapat diambil dari hadis tersebut, di antaranya: ${ }^{16}$

a. Rawi dalam hadis tersebut menyifati orang badui dengan kondisi rambut yang acak-acakan untuk menguatkan periwayatan karena memang benar adanya demikian, bukan karena sikap rawi yang tidak suka.

b. Sholat 5 waktu termasuk rukun Islam, akan tetapi tidak disebutkan namanama dan jumlah rakaatnya karena sudah masyhur.

c. Kewajiban shalat witir dan shalat id dihukumi fardu kifayah tidaklah disebutkan dalam hadis.

d. Wajibnya shalat malam dinasakh menurut ijma'

e. Puasa termasuk rukun Islam, maka tidak ada puasa yang diwajibkan selain puasa Ramadhan.

f. Boleh bersumpah meski tidak dalam keadaan darurat

g. Penolakan terhadap sikap kelompok Murji'ah, karena kemenangan dapat diperoleh sebab ia benar dalam melakukan perbuatan dan tidak menguranginya.

Maka dengan demikian, metode yang digunakan Musa Syahin dalam kitab Fath al-Mun'im adalah metode muqarin, yaitu menjelaskan hadis dengan cara membandingkan hadis dengan hadis yang lain, juga membandingkan pendapat para ulama dalam mensyarah hadis. Dengan metode ini diharapkan akan dijumpai banyak pendapat untuk mendapatkan pemahaman yang luas. Di samping itu, pensyarah yakni Musa Syahin dalam mensyarah lebih banyak pada penjelasan fiqih dengan banyak mengutip pendapat para ulama fiqih seputar hokum dalam suatu hadis.

\footnotetext{
${ }^{16}$ Musa Syahin Lasyin, Fath al-Mun "im Syarh Sahih Muslim, Kairo: Dar al-Syuruq, 2002), juz 1, hlm. 39.
} 


\section{Analisis Kelebihan dan Kekurangan Kitab Fath al-Mun'im Syarh Sahih} Muslim

Dari pemaparan tentang sistematika penulisan dan metode kitab Fath alMun'im Syarh Sabih Muslim, dapat diketahui beberapa kelebihan dan juga kekurangannya, yaitu:

a. Kelebihan

1) Kelengkapan materi yang disampaikan dalam syarah, meliputi penjelasan hadis secara umum, makna perkata, kalimat, kaidah nahwu dan balaghah.

2) Pengarang tidak fokus dengan pendapatnya, namun juga diperkuat dengan alQur'an dan hadis-hadis lain, serta pendapat ulama yang lain.

3) Pensyarahannya tidak sekedar menjelaskan makna perkalimat, tetapi terkadang menjelaskan keutamaan atau faidah yang terkandung dalam hadis.

b. Kekurangan

1) Terkadang tidak mencantumkan status hadis

2) Tidak menyebutkan kualitas rawi

3) Terkadang syarah terlalu meluas sehingga membuat penjelasan sulit dipahami.

\section{Kesimpulan}

Sabih Muslim merupakan kitab hadis yang paling banyak digunakan sebagai rujukan untuk mendapatkan hadis-hadis shahih dari Rasulullah Saw. Oleh karena itu, kitab hadis ini cukup menjadi perhatian banyak ulama untuk memberikan penjelasan atau syarah atasnya, baik dari ulama salaf (klasik) maupun ulama khalaf (modernkontemporer). Kitab Fath al-Mun"im Syarb Sabib Muslim karya Musa Syahin Lasyin merupakan kitab kontemporer yang mensyarah kitab hadis Sabih Muslim. Kitab ini dalam pensyarahannya menggunakan metode muqarin, yaitu menjelaskan hadis dengan cara membandingkan hadis dengan hadis yang lain, juga membandingkan pendapat para ulama dalam mensyarah hadis.

\section{Daftar Pustaka}

Adlabi, Salahuddin Ibn Ahmad. Manhaj Naqd al-Matan Ulama' al-Hadis al Nabawi, terj. Qadirun Nur dan Ahmad Musyafiq. Jakarta: Gaya Media Pratama. 2004. Al-Hajjaj, Abu al-Husain Muslim ibn. Sabih Muslim. Beirut: Dar al-Fikr. 1992. 
Ash-Shiddieqy, Teuku Muhammad Hasbi. Sejarah \& Pengantar Imu Hadis. Semarang; Pustaka Rizki Putra. 2009.

Dosen TH, Fak. Ushuluddin, UIN Suka. Studi Kitab Hadis, Yogyakarta: Teras, 2009.

Imam, Muhammad Aniq. "Problematika Sunnah Tasyri'iyyah dan Ghairu Tasyri'iyyah. jurnal $A D D I N$, vol. 7, no. 2. 2013.

Lasyin, Musa Syahin. Fath al-Mun'im Syarh Sahib Muslim. Kairo: Dar al-Syuruq. 2002.

Masruri, Ulin Ni'am. Methode Syarah Hadis. Semarang: CV Karya Abdi Jaya. 2015.

Muhtador, Moh. "Sejarah Perkembangan Metode dan Pendekatan Syarah Hadis", Riwayab: Jurnal Studi Hadis. Vol. 2, No. 2. 2016.

Mustaqim, Abdul. Ilmu Ma'anil Hadis Paradigma Interkoneksi; Berbagai Teori dan Metode Pemahaman Hadis Nabi. Yogyakarta: IDEA Press. 2008.

Qaradhawi, Yusuf. Kaifa Nata'amal Ma'a Sunnah Nabawiyyah, terj. Muhammad al Baqir, Bandung: Karisma. 1993.

Saifuddin, "FIQH AL-HADITS: Perspektif Historis dan Metodologis, Ilmu Ushuluddin, Vol. 11, No. 2, Juli 2012.

Santosa, Sandi. "Melacak Jejak Pensyarahan Kitab Hadis". Diroyab: Jurnal Ilmu Hadis Vol. 1 No.1 2016.

Suryadilaga, M. Alfatih. Metodologi Syarah Hadis. Yogyakarta: Kalimedia. 2017.

Ulama'I, A. Hasan Asy'ari. "Sejarah dan Tipologi Syarah Hadis". Teologia, Vol. 19, No. 2. 2008 .

Walidin, Farham. "Metode Syarah Syekh Syafiurrahman al-Mubarakfurry", Pascasarjana Ilmu Hadis UIN Sunan Gunung Djati Bandung. 2018.

Zuhri, Muh. Telaab Matan Hadis; Sebuah Tawaran Metodologis. Yogyakarta: LESFI. 2003. 